\title{
Morphology as clue to developmental regulation: stomata
}

\author{
Valentin Krassilov $^{1,}$, , Alex Berner ${ }^{2}$, Sophia Barinova ${ }^{1}$ \\ ${ }^{1}$ Institute of Evolution, University of Haifa, Mount Carmel, Haifa 31905, Israel \\ ${ }^{2}$ Israel Institute of Technology, Haifa, 32000, Israel
}

\section{Email address:}

krassilo@research.haifa.ac.il, vakrassilov@gmail.com (V. Krassilov)

\section{To cite this article:}

Valentin Krassilov, Alex Berner, Sophia Barinova. Morphology as Clue to Developmental Regulation: Stomata. Plant. Vol. 1, No. 3, 2013, pp. 30-44. doi: 10.11648/j.plant.20130103.11

\begin{abstract}
Incipient stomata might have appeared in thalloid alga-like land plants as sporophytic structures homologous to gametangial conceptacles of their isomorphic gametophytes and developed in association with vascular tissue and cuticle. Historically, stomatal evolution is correlated with growth habits and synecological events like the early terrestrial plant expansion from wetland to dryland habitats or the appearance of arboreal and grass canopies. The general tendency of elaboration and aggregation of stomatal complexes was reversed with reduction of vegetative growth at such phylum initiating events as the origin of angiosperms. Stomata links ambient environment with leaf surface air layer and the air of intercellular spaces, balancing the reduction and oxidation reactions involved in photosynthesis. Adaptive responses to environmental change require adjustments of transpiration rates through stomatal density regulation, such as revealed in Ricotia lunaria ecotypes of mesic and xeric slopes of a canyon, with the differences in Stomatal Index comparable to those obtained by experimental exposure to mildly elevated $\mathrm{CO}_{2}$ levels. Long term responses include morphological elaboration of stomatal complexes and their aggregates providing for developmental stability, scarcely impaired by occasional aberrations. Distribution of stomatal complexes correlates with vascularizaton and wax biosynthesis controlled by auxin and ABA hormones respectively at the cell differentiation level. Stomatal transcription factors respond to the interfering auxin/brassinosteroid/ABA signaling mediated by kinaze receptors and their ligands. Stomatal developmental feedbacks are probably conferred by the $\mathrm{pH}$ activated protease and oxidative stress activated ('mitogen activated') protein kinase cascades. This way the hormonal response to environmental pressure is converted into the chemical free energy potential of phosphorylation contributing to internal energy of structural innovation. Universality of this scheme may explain correlation of stomatal development with the whole plant growth habit, ecology and evolution.
\end{abstract}

Keywords: Plant Evolution, Developmental Regulation, Stomata

\section{Introduction}

Plant stomata are epidermal structures mediating the ambient/interior gas exchange, hence falling under physiological and environmental control. As relatively simple superficial structures of a readily traceable ontogeny, stomata represent an ideal object for developmental studies, highlighting interaction of genetic and epigenetic factors.

The molecular level regulation of stomatal development is a fairly advanced topic of the evolution - development ('evo-devo') research, revealing the immense complexity of the intrinsic regulation system [1-14 and elsewhere]. An external control by environmental factors is implied, but commonly relegated to a role of subsidiary regulation with a few 'entries' in the intrinsic regulation network mediated through stress-sensitive regulators $[9,10,14]$.

The system of stomatal transcription factors and their modulators is thoroughly studied in Arabidopsis thaliana, the model plant for molecular developmental research. A limited experience with different species compliments a few regulation modules and reveals specificity of orthologous gene expressions (reviewed in $[12,15]$. At the same time, neither stomatal topography vis-à-vis venation pattern, nor the cell cohesion - cutinization processes are well represented in Arabidopsis (and the other forbs), displaying reduction of vegetative growth and complexity.

Stomata is a cellular structure that is relatively studied in extant as well as fossil plants. The fossil record of stomata encompasses about 400 million years and contains a wealth of data that is poorly explored so far. This paper attempts to relate general tendencies in morphological evolution of stomatal complexes to molecular developmental studies, linking environmental and endogenous regulation in evolution and development. 


\section{Material and Methods}

Material for this work was accumulated through many years of cuticular/epidermal studies in extant and fossil plants, including early land plants, all groups of extant and extinct gymnosperms, as well as early to extant representatives of the phylogenetically basal angiosperm groups, with emphasis on the leaf vein effect on stomatal patterning, developmental anomalies, and guard cell cutinization [16-24]. Problems of environmental impacts on stomatal densities are considered in [25-27]. Stomatal density and morphology have been studied on leaf cuticles and epidermal replicas with light, scanning and transmission electron microscopy. All illustrated materials are studied by the authors. Molecular data are from literature sources indicated in the References, but the authors are entirely responsible for the inferences that may not coincide with those of the sources.

\section{Results}

\subsection{Brief Essay of Stomata vs. Growth Form Evolution}

Pilliteri and Dong [14] support a recent hypothesis of stomata originating only once in plant phylogeny, supposedly in some mid-Paleozoic bryophytic plants. This implies a bryophyte ancestry of vascular plants, which is unlikely on general morphological and paleobotanical grounds. No unambiguous bryophytes are found close to the date of land plant first appearance, about $420 \mathrm{Ma}$ (million years before present). The persistent thick-walled spore tetrads found in the broad interval of about $450-370 \mathrm{Ma}$ might have been as probably produced by the cutinized thalloid plants of Orestovia - Schuguria group with nearly isomorphic gametophyte and sporophyte generations of cylindrical shoots, bearing scattered gametangial conceptacles and stomata-like structures, respectively $[20,24]$. The uncutinized stomata-like structures were shed with growth of the thalli, leaving holes surrounded with concentric rings of encircling cells (Fig. 1).

The derivation of stomata from generative organs is a possibility worth exploring, especially in respect to the role of hormonal regulation discussed later in the paper. In the progenitorial land plants, stomata have appeared together with cuticle and vascular tissue, thus associated from the very beginning of terrestrial plant life.

The evolution of stomatal topography and micromorphology over the history of plant cover (compendia by [22,28-30] is related to the most prominent events in the history of terrestrial vegetation, such as:

- Transformation of radial dichotomous shoot structures in respect to phototropism and apical dominance, related to distribution of growth factors and respective stomata patterning;

- Functional differentiation of photosynthetic organs and leaf appearance on the basis of syntelomic branching systems;

- Adaptive radiation of growth habits (forms) related to land plant expansion from wetlands to drylands;

- Acquisition of arboreal habits, leaf canopies, and deciduousness;

- Spread of herbaceous growth forms and the appearance of grassland canopies;

- Sclerification of leaf tissues and cutinization of leaf surfaces in relation to reduced transpiration and light exposure in arboreal and grassland canopies;

- Diversification of vein patterns and the appearance of minor vein network as a system of transduction and uniform distribution of growth regulators over the leaf blade;

- Leaf blade reduction in phyllodic leaves (derived from expanded petioles with leaf blade reduced or lost);

- Leafy shoot transformation into cladodic leaves through leaf fusion and re-patterning of vascular networks.

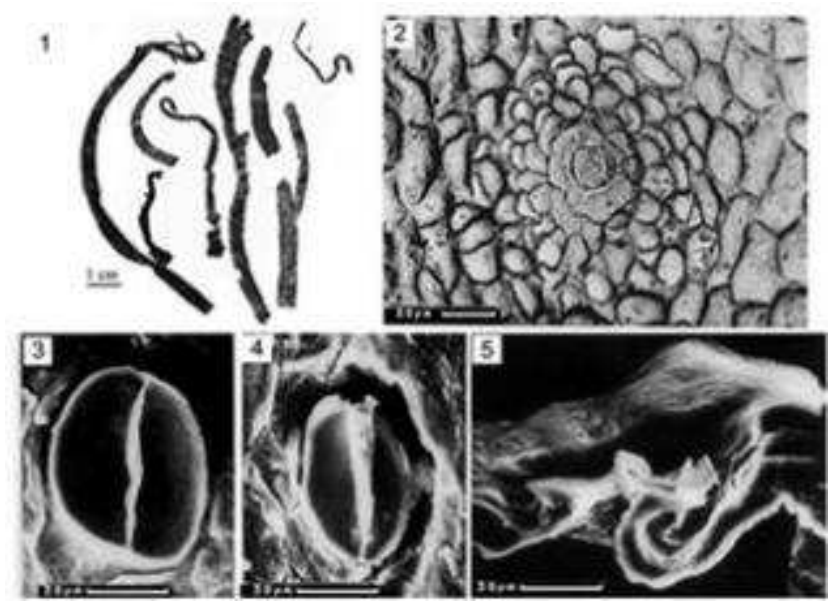

Figure 1. Devonian thalloid plants of Orestovia - Schuguria group with stomata-like structures putatively homologous to gametangial conceptacles, ca. 385 MA, LM and SEM: 1, Orestovia, cutinized thalloids, 2 , conceptacle with a central neck cell in a putative gametophyte ('Schuguria'); 3, 4, stomata-like structures in surface view; 5, stomata-like structure, section transverse to the aperture.

Through history, the diversity of stomatotypes has increased with diversification of plant habits and habitats. The mid-Paleozoic land plants were either fern-like macrophylls with irregular stomatal patterns and poorly differentiated stomatal complexes, or microphyllous lycopsids with crowded, but poorly differentiated stomata on leaf cushions and amphistomatic to epistomatic leaf blades. Typically there was no appreciable gradient of cutinization from ordinary to stomatal cells, and the guard cell cuticular thickenings were lacking or inconspicuous. Such features are primary in pteridophytes and secondary ('paedomorphic') in angiosperms, reappearing in forbs (like the present day Brassicaceae) and summer-green deciduous forms with short-leaved foliage.

In the late Paleozoic, with the appearance of multistoried arboreal vegetation, the prevailing foliar type was phyllodic with parallel to flabellate venation as in cordaites and ginkgophytes. Thick cuticle, thick veins, ridged surface, and stomata crowding in intercostal grooves are the inherent cauline features in leaf petioles conserved in phyllodic leaves as their characteristic surface micromorphology. In 
such foliage forming extensive leaf canopies, elaboration of stomatal structures and patterning are related to leaf xeromorphism, including sclerification, or prominence of mechanic tissues, and cutinization, or high rate wax biosynthesis. Specialization of subsidiary cells, distinct from ordinary cells in arrangement, size, cutinization and associated trichome development, has led to differentiation of stomatal complexes and their aggregates. The prevailing stomatotype was encyclocytic, with radial subsidiary cell arrangement, retained in modern cycads and conifers, but modified in respect to the increasingly well marked filing of stomatal complexes.

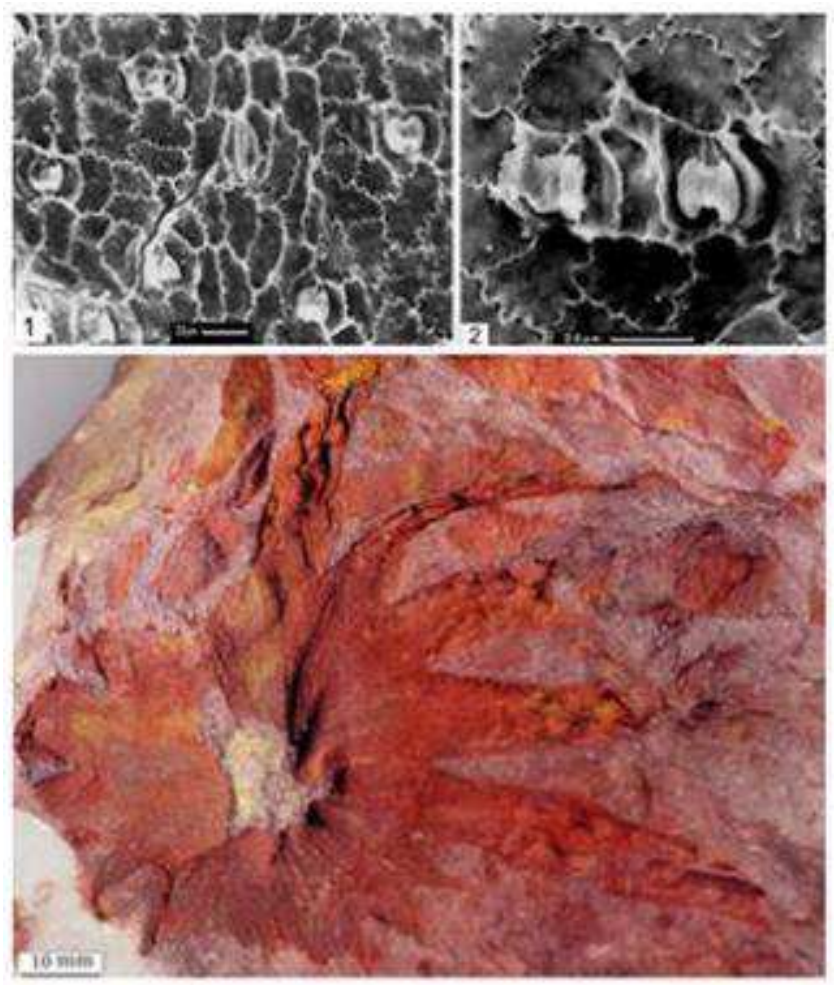

Figure 2. Syndetocheilic (double-lip) bennettitalean stomata in Nilssoniopteris sp., Jurassic, ca. 160 Ma, SEM; 1, aberrant stoma with unaccomplished guard cell differentiation (center) midway between secondary veins; 2, contiguous stomata adjacent to a secondary vein [19]; 3 , bennettitalean whorl of basally fused microsporophylls, mid-Jurassic, ca. $170 \mathrm{Ma}$.

Halted by extinctions at the Permian - Triassic boundary, the buildup of growth form diversity then continued through the Mesozoic, with the advent of pachycaul (unbranched or sparsely branched thick-stemmed) and rhizomatic forms with macrophyllous leaf crowns or reduced cauline leaves. The appearance of double-lipped (syndetocheilic) stomatotype in bennettites, an extinct proangiosperm group, was correlated with pachycauly and whorled disposition of floral parts (Fig. 2). Although not all bennettites were pachycauls, the syndetocheilic stomatotype was conserved in this diverse group (the less specialized subsidiary cell configurations occurring in floral bracts). These stomatal morphologies are chronologically correlated with a spread of monosulcate pollen morphologies. Nearly lost with bennettites extinction near the end of Cretaceous, about 65 MA, a modified form of syndetocheilic stomata has been later recovered in flowering plants.

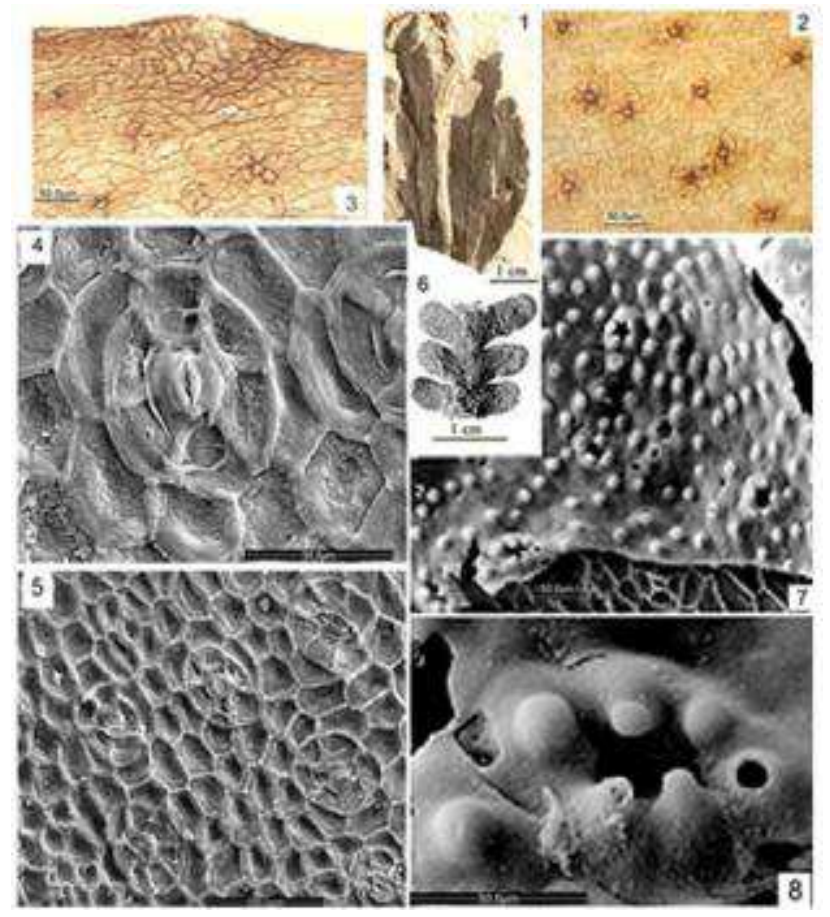

Figure 3. Prototypes of the cycadophyte $(1-5)$ and ginkgophyte $(6-8)$ stomatal complexes in the Permian peltasperms, ca. $280-251 \mathrm{Ma}$, SEM and LM [26,27].

In seed plant phylogeny, stomata complexes display evolutionary conservatism or a gradual increase in complexity, or else a radical restructuring depending on growth form evolution. Peltasperms, a diverse group of Permian gymnosperms, gave rise to the sister groups of Mesozoic ginkgophytes and cycadophytes, their divergence starting at the ancestral level already. Fig. $3(7,8)$ shows a peltasperm stomatal complex with strong papillae on subsidiary cells converging over stomatal pit as is typical of Mesozoic gnetophytes. Fig. 3 (2-5) illustrates a different type of subsidiary cell specialization, uniformly cutinized and intruding the stomatal pit, characteristic of extinct cycadophytes, as well as modern cycads first appearing in the Late Cretaceous [31]. In extant Cycas revoluta (Figs. 4-6), stomatal complexes are relatively advanced in terms of morphological complexity and integration, coalescent into a raised 'chimney' of twice more numerous radial increments, with a narrow external opening above the guard cells. Phylogenetic continuity is far less obvious in Mesozoic bennettites revealing a radical restructuring of the radial stomatotype (Fig. 2) in relation to the stunted pachycaul habit and floral phyllotaxis.

Angiosperms first appeared as weedy rhizomatous geophytes with scanty cauline leaves [24]. Early angiosperm leaves are thinly cutinized, with simplified stomatal patterns and structures converging on those of pteridophytes. Stomatal complexes degraded to simple stomata surrounded with unspecialized cells, and radial arrangement of uniform 
subsidiary cells gave way to haphazard anomocytic ('ranunculoid') configuration, correlated with the appearance of tricolpate pollen (although the most advanced group of higher plants in terms of morphological complexity and diversification potentials, angiosperms are liable to neotenic/paedomorphic transformations related to accelerate development and compensation of functions, like the loss of archegonia in gametophyte development and the loss of the primary arboreal habit in monocots).
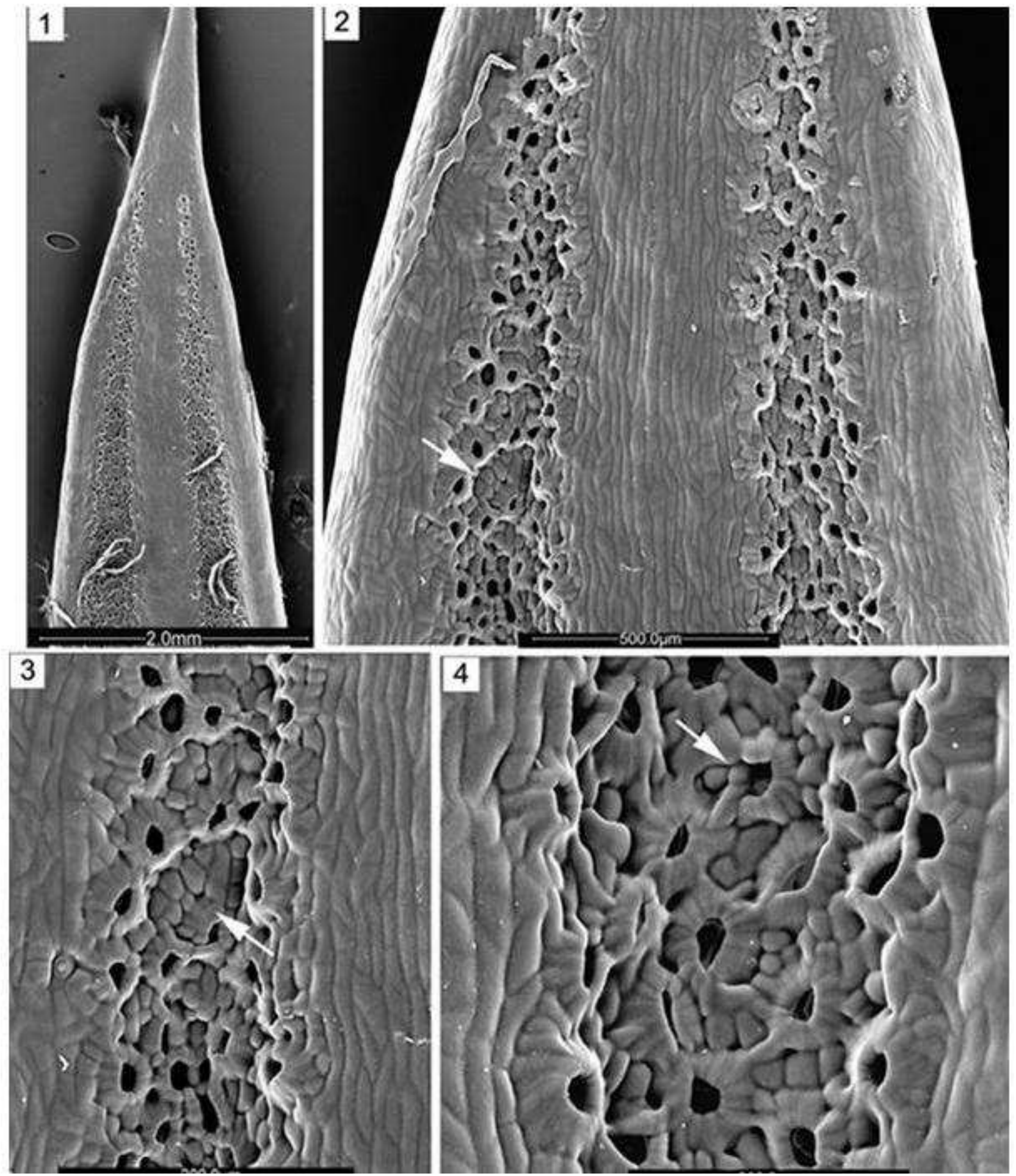

Figure 4. Cycas revoluta, stomatal grooves near the pinna apex, SEM; 1, with few hairs left; 2, 3, showing islands of small cells at the sites of failed stomatal differentiation (arrows); 4, showing unaccomplished subsidiary cell differentiation, putative sdd effect.

Through the mid-Cretaceous, about 120 - 90 Ma, angiosperm diversity rapidly increased, giving rise to leptocaul and fewer pachycaul evergreen and deciduous arboreal forms. Broadleaf canopies and deciduousness 
progressively increased with continental climates spreading toward the end of Cretaceous, about 65 Ma. Mesic grasslands first appeared close to this date, but xeric grasslands are of a much later origin, expanding their ranges through the Neogene. The prevailing tendency of leaf evolution was phyllodic again, resulting in the typical monocot leaf, parallelodromous with cross veinlets.

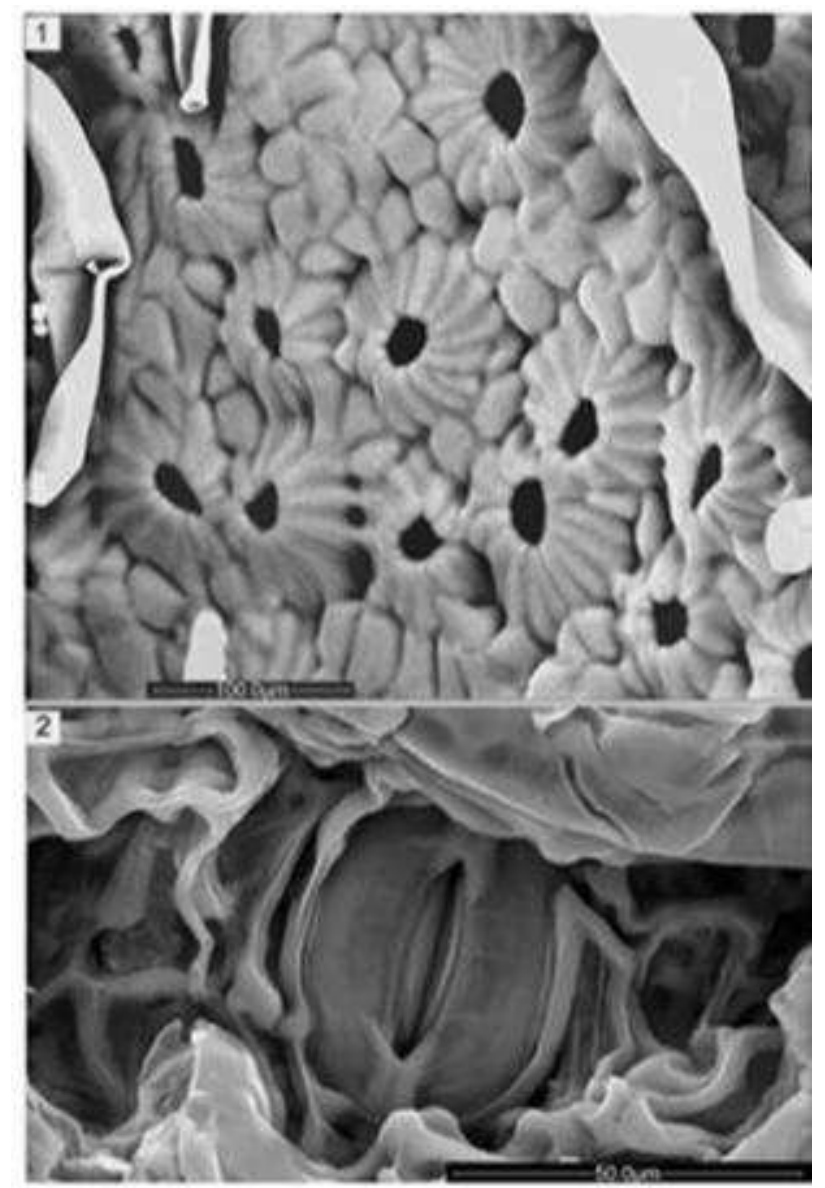

Figure 5. Cycas revoluta, stomatal structures, SEM: 1, contiguous chimney complexes of coalescent subsidiary cells intermingled with hairs and the island of small cells (failed stomatal differentiation); 2, stoma, interior view through hypodermal network

While the secondarily reduced stomatal complexes were retained in some deciduous broadleaves and aquatic angiosperms, diversification of stomatotype diversity based on subsidiary cell configuration is congruous with the adaptive growth form radiation. Both cutinization of leaf surface and sclerification of vascular bundles were enhanced with the appearance of evergreen leaf canopies, in particular in laurophyllous forests, with convergently uniform leaf morphology characterized by regular higher order venation, abundance of secretory structures, relatively thick cuticle and sclerification of subepidermal tissues. These features associate with laterocytic, double-lip (syndetocheilic), and tetracytic stomatotypes gaining in importance with the warming trends over the Paleocene - Eocene boundary, about $55 \mathrm{Ma}$, for which such stomatotypes provide phytostratigraphic markers, and then in the Early Miocene, about $20 \mathrm{Ma}$. In modified forms, tetracytic stomatotypes, probably inherited from gnetophyte precursors, dominates the stomatography of Miocene to present day xeric grasslands.

This brief essay leads us to conclude that stomata, although functionally and morphologically conservative structures, have experienced notable historic changes presumably owing to holistic effects of the whole plant growth form evolution. However, the effect of venation on stomatal patterning, as well as cutinization effect on stomatal clustering and morphological elaboration persist through times and taxonomic differentiation.

\subsection{Stomatal Complexes and Aggregations}

Stoma is a two-cell structure presenting a few distinctive features that are related to cutinization of apertural ledges and the polar extensions. In the stomata rush with the leaf surface, cutinization is feebly if at all developed, but in sunken stomata with massive T-shaped polar fixtures it is sometimes quite elaborate (examples below). Generally, morphological elaboration is correlated with construction of stomatal complexes (also called stomatal apparatuses) that include stoma proper and surrounding cells for which it is a focus of spatial orientation and morphological differentiation through development. Scattered stoma surrounded with unspecialized neighbor cells is the most reduced (underdeveloped) form of this plant organ, although it is found in both archaic spore plants and advanced groups of flowering plants.

The subsidiary cells next to stoma contribute to stomatal functioning by transmitting water and mineral solutions, as well as protecting stomata from overwatering and parasitic intrusions, thereby functionally specialized and morphologically to an extend differing from ordinary epidermal cells (cover or 'pavement' cells) in shape, size, configuration, and cuticular features.

Subsidiary cell configuration is conservative and diagnostic for plant families and higher rank taxonomic divisions, whereas encircling cells are less constant. Developmentally subsidiary cells are mesocytic, produced in meristemoid line, or paracytic, recruited form adjacent cell lines, or mixed (mesoparacytic). In seed plants, the most widespread configurations of subsidiary cells are radial or concentric, of regular shape and alignment, as well as evenly cutinized. Alternatively, they form an irregular ring of unequal cells (the anomocytic configuration considered primitive in dicots), or the lateral (parallel to the aperture) and polar subsidiaries are conspicuously different in shape and dimensions, as in the double-lipped (syndetocheilic) arrangement.

There are not yet fully understood relationships between phyllotaxis, in particular the arrangement of floral parts, and 'cellotaxis', the regularity of subsidiary cell disposition, with stoma as a virtual axis. Thus radial subsidiary cells are correlated with a compressed spiral phyllotaxis in both scale-leaved conifers and megaphyllous cycads, whereas tetracytic stomata commonly occur in coniferoids 
(Quadrocladus), gnetophytes and angiosperms with decussate leaves. The cruciferoid stomatotype is confined to 'cross-bearing plants' (Brassicaceae). The double-lipped complexes have appeared in association with stunted growth, pachycaul habit, cauliflory, and whorled floral parts (Fig. 2).
Such correlations can be seen as fractal (when a basic structural motif is recapitulated in derived structures), owing to the whole plant growth regulators, in particular the auxins and other hormones [32].
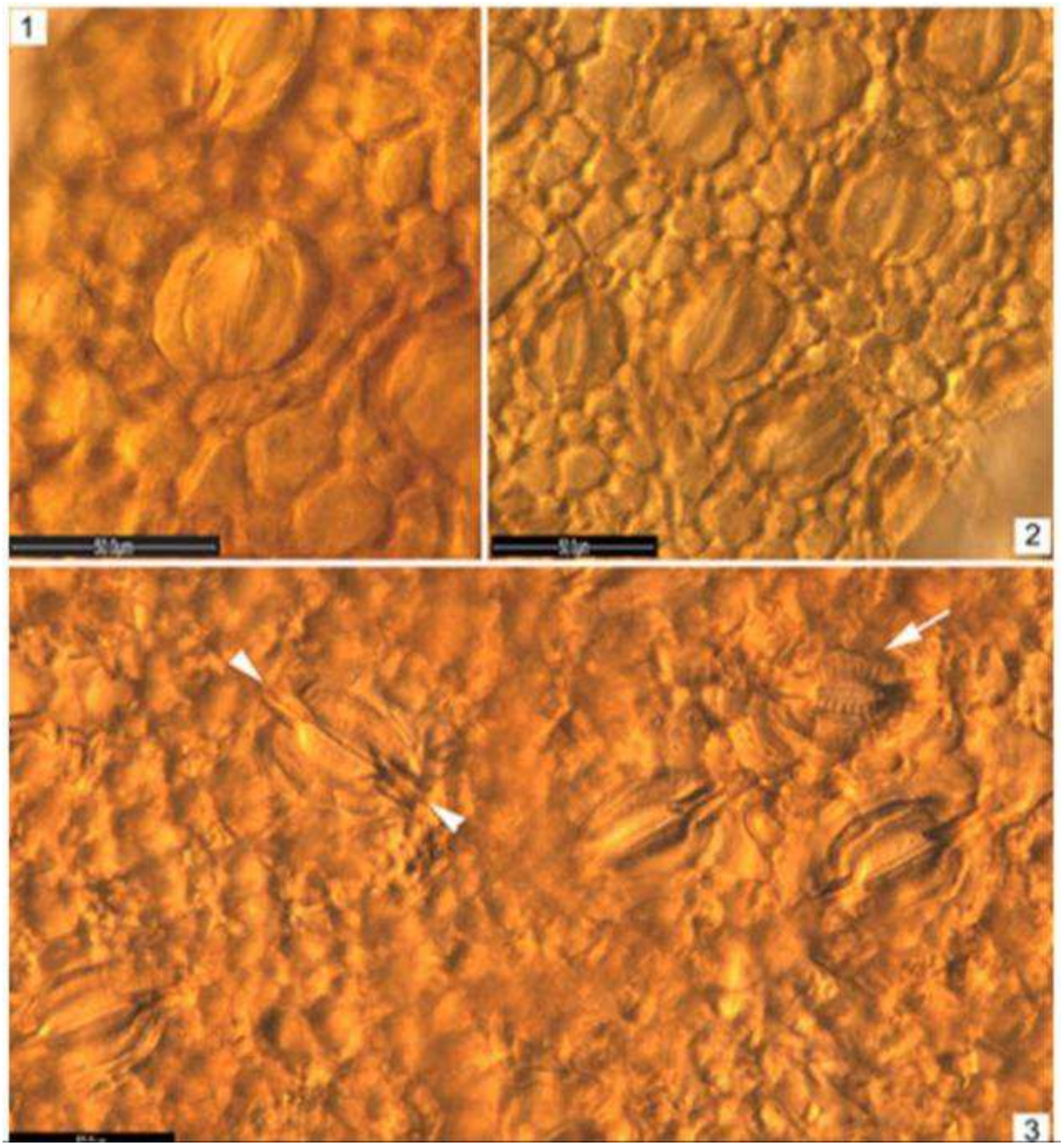

Figure 6. Cycas revoluta, LM, interior view: 1,2, stomata surrounded by the fringes of the subsidiary cell 'chimney' above them; 3, stomata at the level of hypodermal tissue, arrowheads on T-shaped polar bars, arrow on striate apertural ledges, an aberration like in the double tmm; flp effect.

The transition from specialized to unspecialized cells can be gradual, with encircling cells as intermediates, or quite sharp, as in Cycas revoluta with numerous (about twelve) radially aligned subsidiary cells, flush with each other forming a chimney over the guard cells, with an orifice exposing very little of the aperture (Fig. 5). The cuticle of the 'chimney' is a uniformly thick layer with anticlinal cell walls feebly marked. The guard cells are sunken in the holes of hypodermal network and are seen on the interior side of it. A more complicated arrangement has both guard cells and 
subsidiary cells sunken under the dome of encircling cells that are tightly sealed to each other and thickly cutinized.

In such cases, it is meaningless to include subsidiary cells in the counts of spacing cells between adjacent stomata, because they are not beside, but above stoma, making a fairly distinct stomatal complex or 'apparatus', an organ of considerable complexity in comparison with unspecialized stomata. When calculating stomatal indices it makes sense counting stomatal complexes as units, which is how they are in fact perceived. We made several such counts obtaining figures comparable with stomatal indices for plants with scattered stomata, but when subsidiary cells were separately counted the results turned out totally incongruous. Therefore, structural complexity makes stomatal functioning less dependent on occasional morphological variation.

The chimney-like stomatal complexes occur in the other extant and fossil cycads, peltasperms, and conifers, with the number of radially aligned subsidiary cells matching that of Cycas, but less prominently raised. However in Cycas the stomatal organogenesis does not stop at the chimney-like stomatal complexes, but goes further to create stomatal grooves, the narrow troughs on both sides of the midrib, containing densely packed stomata and glandular hairs. Stomata never occur outside the grooves, which are thus fairy distinct structures with sharp parallel margins, wedging out before the apical mucro. Stomatal density and cutinization are uniform over the groove as a whole, suggesting a balance of inhibiting and promoting factors under the developmental integrity of stomatal groove as aggregation of stomatal complexes. Hairs may contribute to uniformity of microclimate and gas concentrations over the groove. They are denser on slopes of midrib and marginal rolls, but are mixed and developmentally interchangeable with stomatal complexes over the grooves. No specific association of hairs with the small cell patches is discerned. Anyway, hairs are parts of stomatal grooves as integral epidermal structures. Yet locally the stomatal complexes are irregularly clustered with patches of small isometric cells intruding between the clusters (Figs. 4, 5).

Stomatal clustering is controlled by a complex system of endogenous and external regulators discussed below. Notably, small cell patches in stomatal grooves of Cycas resemble the effects of overexpressed SPEACHLESS $(\mathrm{SPCH})$, interfering with stomatal initiation, but their association with irregularly clustered and contiguous stomatal complexes (Fig. 5) betrays the effect of the putative receptor protein kinase TWO MANY MOUTH (TMM) [33], assisting in regulation of stomatal initials, as well as and its processing ligands, in particular the EPIDERMAL PATTERNING FACTORS (EPFs) excreted by meristemoid mother cell [34] and STOMATA DENSITY AND DISTRIBUTION (SDD) affecting the subsidiary cell differentiation [1] as components of the hormone signaling pathways [13]. The double tmm; flp effect described in [33] and so called fama tubers [35] are recognizable in Cycas and even in the Permian peltasperms, suggesting uniformity of regulatory signal processing pathways through time and taxonomic differentiation.

In general terms, stomata clustering is a compromise between differentiation and integration of cellular structures, an incipient form of which is stomatal pairing, a fairly common phenomenon in both gymnosperms and angiosperms (Figs. 3, 7) related to a mild flp effect, perhaps added with a slight ssd effect on subsidiary cell configuration. One stoma of a pair is usually underdeveloped, but without impairing functionality. The pair 'join forces' in inhabiting stomatal initiation in the vicinity, resulting in a greater than average distance between the pair and the adjacent solitary stomata, as well as a more compact subsidiary cell configuration. Less commonly, stomata are paired with epidermal hairs, presumably an initial condition for hairy stomatal grooves in cycads and taxaceous conifers.

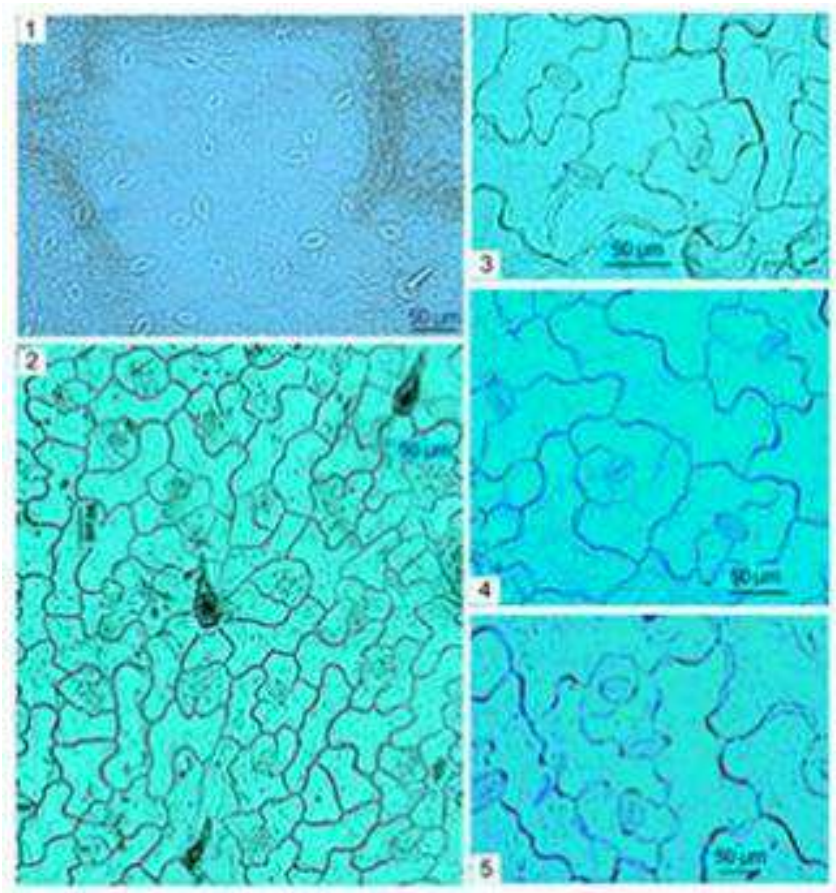

Figure 7. Ricotia lunaria, LM: 1, mesic slope ecotype, adaxial cuticle: 1, stomatal arrangement against the minor vein areole, arrows on paired stomata; 2, stomatal disposition arrangement against trichome; $3-5$, stomatal clustering.

Spacing rules for regular stomatal arrangements over stomatal files, bands or grooves are different from those for scattered stomata, in which the numbers of spacing cells vary in respect to the distance from leaf veins or glands (above) and environmental control. In contrast, in crowded stomata of a stomatal band or groove, metrical spacing does not depend on numbers of spacing cells that are usually much smaller than stomatal complexes. Stomatal files and grooves display a cumulative suppression effect on the neighboring stomata-free zones, acting as units of epidermal differentiation, while their internal morphogenic gradients are smoothed out. 


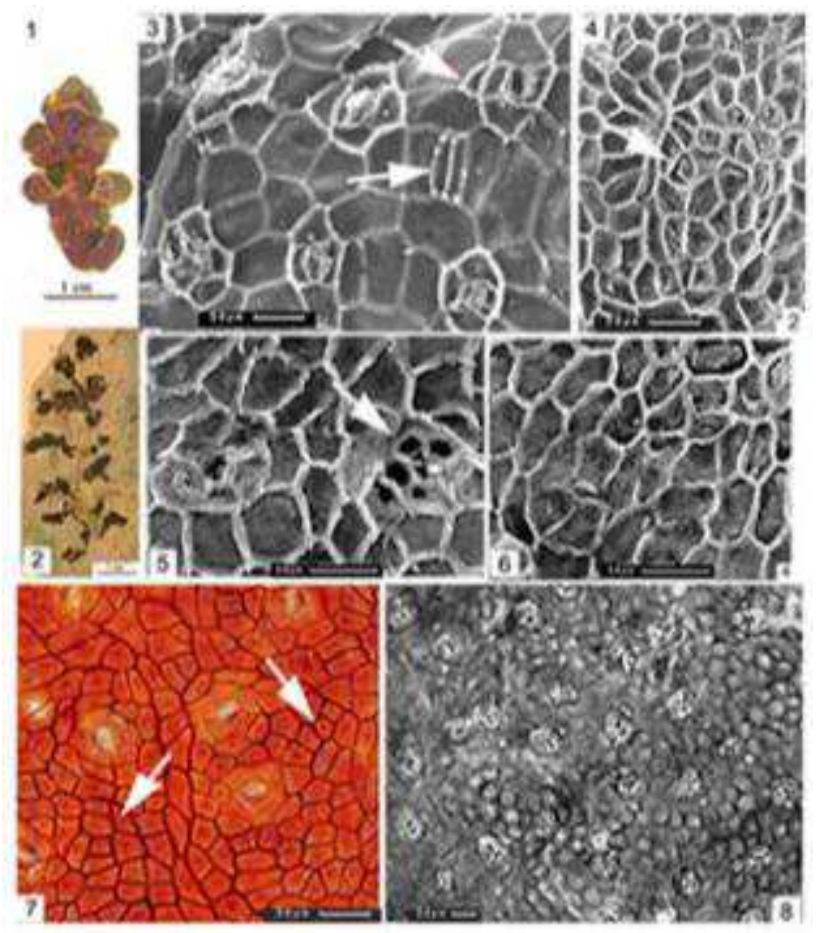

Figure 8. Stomatal aberrations related to leaf fusion in phylloclades, ca. 251 Ma, SEM and LM: 1, 2, stages in pylloclade formation; 3, flp and fama-like guard cell expressions (arrows); 4, tmm-like cluster; 5, spch-like cluster, 6, stomatal pairing; 7, 8, tmm-like clusters at the sites of failed guard cell differentiation (arrows); [26].

It must be noted here that complexity of stomatal organization correlates with growth form rather than phylogeny (unless 'phylogeny' tacitly follows growth form evolution). Stomatal aggregation as a step in epidermal organogenesis might have been lost in initial dicots in relation to elaborate minor vein networks and blind vein terminating hydathodes that can be seen as auxin distribution framework, providing for this hormone uniform concentration over the leaf blade, radically different from alternation of auxin peaks and troughs in gymnosperms with parallel or two-ranked pinnate venation.

\subsection{Stomatal Development and Cutinization}

When stomata develop on one side of leaf blade (hypostomatic or epistomatic), their presence is as a rule inversely correlated with thickness and chemical resistance of leaf cuticle, a waxy polymer membrane over the surface wall of epidermal cells penetrating some distance along their anticlinal walls. Cuticle affects cell wall permeability to water and $\mathrm{CO}_{2}$ as well as moderating the effect of light intensity, thus essential for stomatal functioning. In accomplished stomatal complexes with sunken guard cells, cutinization decreases over a gradient from the border of stomatal pit over subsidiary cells and the rings of encircling cells.

A thick cuticular ridge (Florin's ring) is commonly formed around stomatal pit as a coalescent structure over the proximal walls of subsidiary cells. Prominent cuticular trichomes may develop over the ring overhanging the pit. However, when subsidiary cells are sunken together with guard cells, they are relatively feebly cutinized. In such cases stomatal pit is bordered by encircling cells with a thicker cuticle.

Cutinization contributes to formation of stomatal complexes by promoting proliferation, as well as coalescence of subsidiary cells. In seed plants, the statistically normal number of subsidiary cells varies between four and six, but in the fossil conifer genus Ulmannia and in extant Cycas revoluta they are about twice as numerous. Although resembling subsidiary cell proliferation under a mild fama effect in Arabidopsis [35], such complexes are constant and evolutionary conservative structures of regularly aligned and laterally coalescent cells, with strongly and evenly cutinized surface walls. The guard cells of stomatal complexes develop a 'cutin skeleton' of apertural ledges, periclinal thickenings, polar T-shape thickenings and anticlinal papillae over the inner cavity. These features have some taxonomic significance [16], but are lost in simple stomata with unmodified subsidiary cells.

Irregular clustering of stomatal complexes is associated with patchy cutinization, whereas stomatal files and grooves are uniformly cutinized as integral structures. The cutinization effect on the coherence and coalescence of cellular structures complies with broad involvement of wax biosynthesis in organ fusion and integration of compound structures related to environmental stresses, in particular draught resistance [36-39]. Wax biosynthesis transcriptional regulators like HIGH CARBON DIOXIDE (HIC) are expressed in stomata, conferring a peculiar guard cell expression with radial bars on apertural ledges [36], discernible in Cycas also (Fig. 6). The MYB group of transcription activators involved in the abscission acid (ABA) mediated draught responses [40] participate in shaping stomatal complexes redundantly or additively to FAMA and FLP [6].

We studied stomatal structures in fossil plants from the transitional Permian - Triassic assemblages survived over the greatest environmental crisis in earth's history [26]. In the Volga River region, they are dominated by two short-lived genera, Permophyllocladus and Vyaznicopteris, both cladodic, and the former showing consecutive stages of leaf fusion on the way from scale-leaf shoots to irregularly lobed blade with pinnate venation. Heavy phylloclade cutinization correlates with elevated Stomatal Index and relatively high frequency of stomatal anomalies (Fig. 8), such as irregular patches of concentric cell files without stomata, resembling cell configurations in Arabidopsis ascribed to inhibition of incipient guard cell differentiation, the mute effect associated with auxin maxima [11]. These are accompanied with doubling and overlap of guard cells, the regulation disorders comparable to the double tmm; flp effect in Arabidopsis [33]. Draught is considered to be the major stress factor over the Permian - Triassic transition, although in our estimates the boundary interval at about 251 Ma was not excessively dry. We thereby related the high 
frequency stomatal aberrations to the long-term draught effect, conferring coalescence, fusion and transformation of macrophyllous leafy shoots into compound leaf blade accompanied by stomata clustering and aggregation of stomatal complexes induced by activators of wax biosynthesis and cutinization.

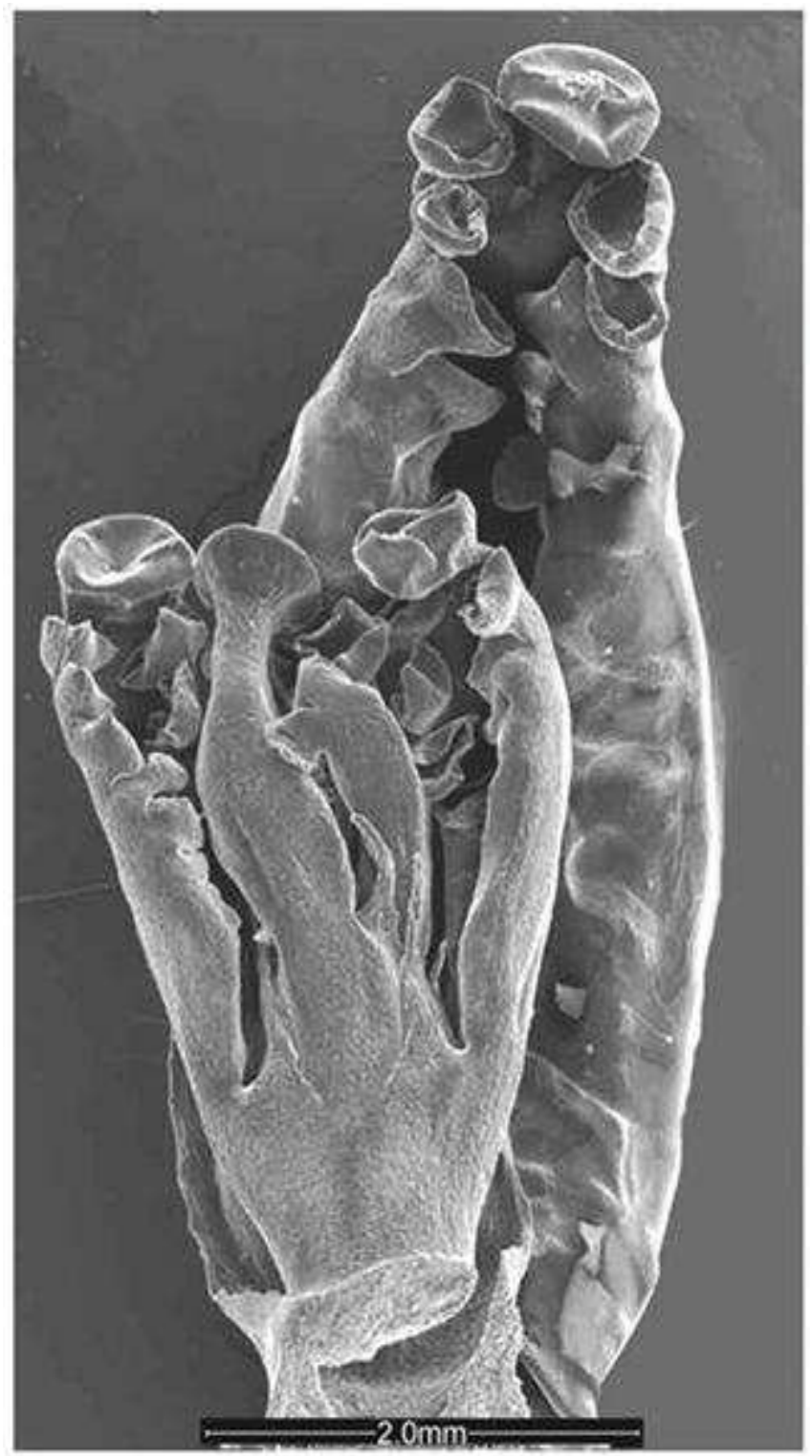

Figure 9. Cercidiphyllum magnificum, glands on primordial leaves [23].

\subsection{Stomatal Patterning Framework}

Leaf tips, meristematic through leaf development, are as a rule devoid of stomata (Fig. 4). The localizations of marginal meristem are avoided, in particular when the margins are glandular, inrolled or contoured by intramarginal veins. Glands associate with meristematic activity and control propagation of vascular bundles and distribution of stomata since the appearance of primordial leaf blade. In Cercidiphyllum, a relict arboreal broadleaf still forming leaf canopies over its relict ranges, primordial leaf develops a large apical gland soon followed by a few marginal glands forming a framework for leaf extension and propagation of major veins (Fig. 9). These features dominate epidermal differentiation, although glands fade out in adult leaves. In a precursory Cretaceous species, glands have been retained in adult leaves as well [23].

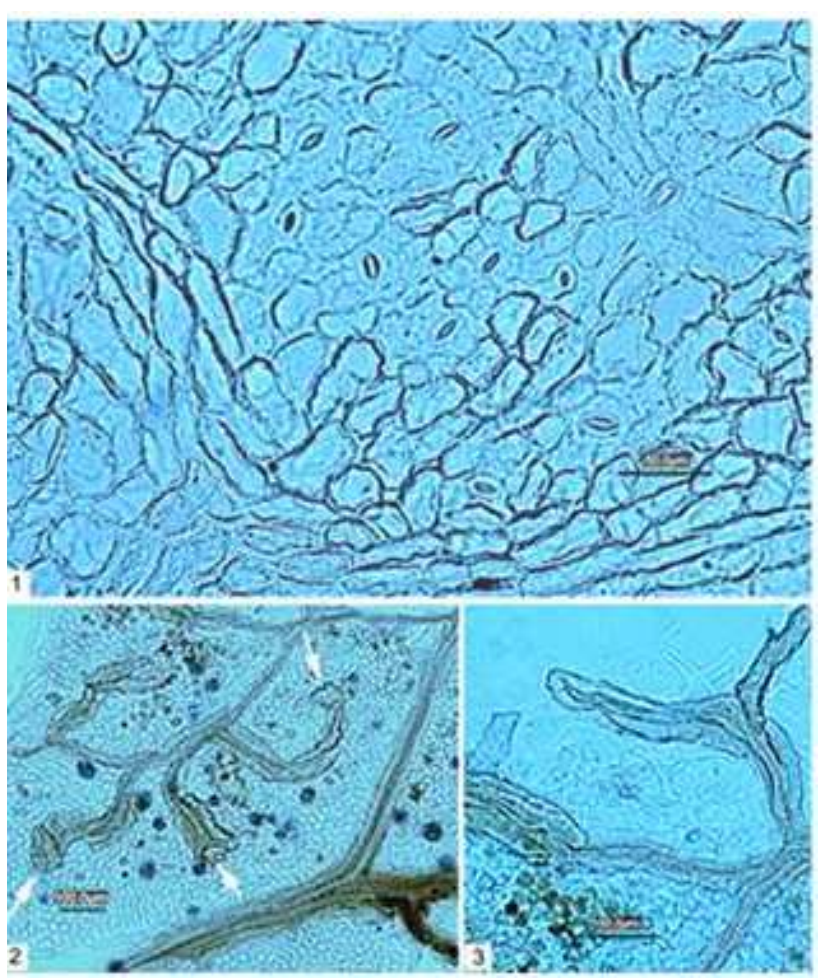

Figure 10. Cercidiphyllum japonicum, SEM, 1, stomatal arrangement in a minor vein areole; 2, 3, blind veins showing bundle sheaths and hydathodes on ends (arrows); [23].

Stomata are sparse or lacking over strong veins (costae), thus forming a characteristic pattern of stomatal and stomata free zones. The effect of venation on stomatal topography is obviously related to vein prominence, the relief they form, therefore inflicted not so by vascular bundles as such but by their sheaths of mechanical tissue. In leaves with parallelodromous or flabellate venation, stomata normally occur in intercostal bands stretched parallel to the veins. Over the bands, stomata are arranged in longitudinal files or irregular. When distinct, stomatal files are separated by one or more files of ordinary cells that are somewhat raised, forming a ridge/groove microrelief. Stomatal filing is aligned with the course of hypodermal fibers beneath, and regularity of stomatal orientation conforms to the hypodermal framework, with stronger elements parallel or perpendicular to the midrib.

In leaves with areolate venation, typical of angiosperms, stomata are confined to areoles bound by tertiary or sometimes also the higher order veins. Stomatal apertures are orientated along the bordering veins at the periphery of areoles, but irregular in the middle. Minor veins are variably if at all reflected in epidermal cell patterning depending on their sheath development that in Cercidiphyllum, a canopy tree, are thicker than in Ricotia, a tiny forb growth form of a 
phylogenetically advanced crucifers (Figs. 10, 11). The effect of blind veins, intruding the areoles, depend on their association with hydathodes, thus noticeable in Cercidiphyllum, but less so in Ricotia (Fig. 7).

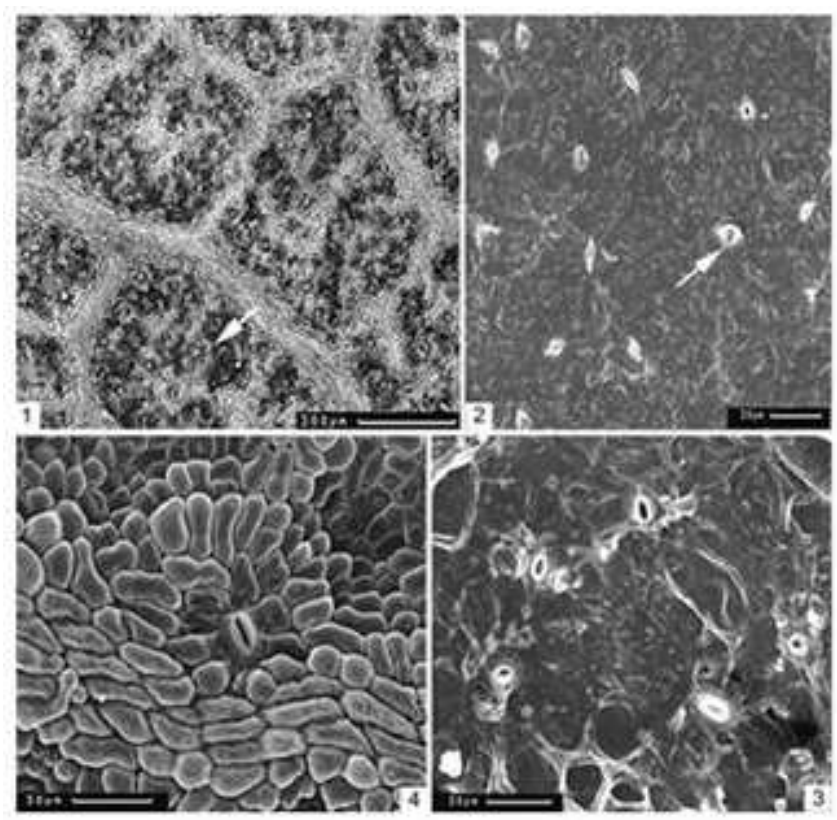

Figure 11. Cercidiphyllum japonicum, SEM: 1, minor vein network, arrow on a hydathodes; 2, hydathodes at arrow in (1); 3, 4, concentric arrangement of stomata around hydathodes (arrow); [23].

Generally, the vein effect is more prominent in stomatal complexes and aggregations like stomatal grooves (above), thus increasing with complexity of stomatal clustering and integration of compound clusters. Since vein sheaths, glands and hydathodes the foci of auxin concentration [41-46], the topographic regularities of stomatal patterning indicate the cardinal role of this growth regulator and its signaling pathway mediators, although its direct effect on co-expressed stomatal regulators may not be evident [11]. In Arabidopsis, the thickvein mutation is involved in polar auxin transport [45]. Auxin concentration has a ridge/trough structure that explains the stomatal density gradients over the vein - gland framework, as well as the anomalous frequencies of contiguous stomata over the borders of stronger veins [19] that are the auxin troughs alongside the bundle sheath ridges.

\subsection{Environmental Effects}

Correlation of stomatal density with the ambient $\mathrm{CO}_{2}$ levels was experimentally confirmed for a large number of higher plants. However, stomatal responses to $\mathrm{CO}_{2}$ fluctuations are neither uniform through the plant world, nor linear [47-51]. Large standard error is a serious limitation of the paleoclimatological $\mathrm{SI} / \mathrm{CO}_{2}$ method [52]. Drought and light intensity invoke SI fluctuations antagonistic to $\mathrm{CO}_{2}$ effect, suggesting that historic trends in SI convey a compromise effect, varying in respect to surface air layer characteristics $[25,53]$ and subepidermal environment.
Environmentally induced SI variations are the focus of experimental work, but insufficiently studied in nature (see [49]. We addressed this problem in studying stomatal patterns in morphologically distinct ecotypes of Ricotia lunaria (Brassicaceae), growing on north facing mesic and south facing xeric slopes of the Oren Canyon near Haifa, Israel. The mesic slope ecotype is more erect and less bushy, with somewhat less dissected leaf blades than in the xeric slope ecotype. The possibility of their genetic differentiation is discussed in [54]. Upregulation of genes putatively homologous to light sensitive genes in Arabidopsis, a taxonomic ally, was preliminarily revealed by microarray gene expression analysis (Leonid Brodsky, unpublished). The abaxial SI is appreciably higher (Fig. 12) and adaxial stomata are more regularly developed in the mesic slope ecotype. The variation is of the same scale as inflicted by experimental $\mathrm{CO}_{2}$ effect, but the results are yet to be verified for controlled conditions. Insofar as ephemeroid Ricotia lunaria ecotypes are separated by a canyon less then hundred meters wide, a $\mathrm{CO}_{2}$ effect is unlikely, and water stress is minimal in spring. Evergreen woodland is much denser on mesic slope, thus producing a considerable shade effect converted into different transpiration rates upon the scheme discussed below.

\section{Discussion}

What is known of stomatal density regulation suggests that steady decrease of $\mathrm{SI}$ owing to technogenic $\mathrm{CO}_{2}$ contribution is an oversimplification of stomatal responses to environmental change. Urban developments and industrialization place high demands on water resources, whereas reduction of natural plant cover enhances desertification tendency, with effects on cloudiness and light intensity. The effects of $\mathrm{CO}_{2}$ and light intensity are opposite or synergistic depending on the light spectrum, sensitive period, $\mathrm{pH}$, and transpiration rates $[9,11,55]$.

In the common type photosynthesis, light energy and water are used to reduce carbon dioxide that is converted into carbohydrate:

carbon dioxide + water + light $\rightarrow$ carbohydrate + oxygen + water

Carbon dioxide consumption and oxygen release through hydrolysis are regulated by light and electron donor (water) availability. At elevated $\mathrm{CO}_{2}$ concentration, an increase in photosynthetic carbohydrate production is accompanied with hyperoxia of intracellular environment that is damaging for plant tissue. This can be countered by a decrease in water transpiration by means of reduced stomatal density. On the other hand, an increase in light intensity and leaf surface temperature increase transpiration rates and induce subepidermal hypoxia, with a positive effect on stomatal density.

Thus environmental regulation of stomatal development can be represented as interaction of light intensity, transpiration rates, and the leaf surface $\mathrm{CO}_{2}$ concentration with effects on redox potential and $\mathrm{pH}$ of subepidermal 
intercellular environment. At the same time, the SI response is more pronounced in plants with scattered stomata of simple structure than in those with clustered stomatal complexes and aggregations. $\mathrm{CO}_{2}$ effect on specialized subsidiary cells of stomatal complexes does not alter the SI (e.g. [9]. Thus morphological complexity of stomatal structures seems to increase developmental homeostasis in respect to environmental stresses.

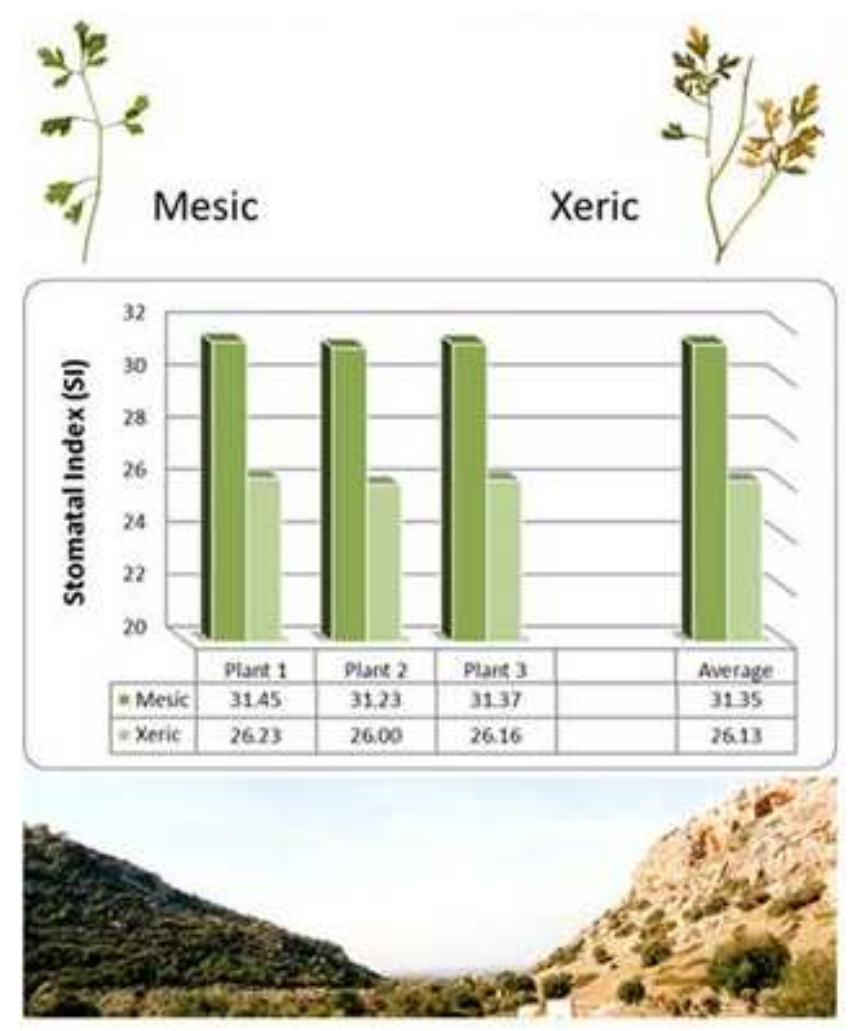

Figure 12. Ricotia lunaria ecotypes on mesic (left) and xeric slopes of the Oren Canyon, Haifa, Israel and Stomatal Index (SI) variation.

In Arabidopsis, the SI effect on stomatal density experimentally modulated by exposing leaves to elevated $\mathrm{CO}_{2}$ is transmitted to new leaves developing under ambient $\mathrm{CO}_{2}$ concentration $[49,56]$. Such a long distance signaling effect unequivocally indicates the induction by plant hormones transmitted through vascular system (xylem and phloem/cambium for ABA and auxins, respectively) as well as the polar cell to cell transportation. Some researchers find long distance signaling illusive, but it was shown to be administered by brassinosteroids [13], usually associated with auxin. Elevated $\mathrm{CO}_{2}$ concentration demonstrably causes a significant increase in auxin, cytokinin and GA concentrations, but decrease in ABA [57].

Differentiation of epidermal areas of stomatal aggregation is attuned to the leaf surface environment (gas concentrations in the surface air layer, light intensity, and moisture) in response to epidermal microrelief of the vein network, glandular trichomes and hydathodes subject to auxin regulation [44]. At the same time draught resistance is conferred by wax gene activators and transporters [38-40,58-60] involved in ABA signaling at the base of stomatal clustering regulation.

Auxins and $\mathrm{ABA}$ are universal plant growth factors with antagonistic effects on cell division and differentiation, but their signaling pathways are coordinated through the retinue of transcription activators and the target feedbacks, forming an integral regulation system. Auxin polar transport is dynamically regulated by PINs localized in cell wall membrane and, among other functions, responsible for phototropism, thus linking auxin efflux to light intensity.

PINs are strongly upregulated in apical meristems, defining the patterns of auxin concentration in developing organs [61,62]. Auxin binding may induce autophosphorylation of PIN genes that initiate or activate the receptor protein kinase cascades involved in auxin signaling, in particular an ERECTA (ER) family extracellular receptor [63], complementing the TOO MANY MOUTH (TMM) receptor of a crucial role in stomata initiation. Mutant tmm expressions are associated with mutant stomatal transcription factors at the sequential stages of guard cells differentiation [33 and elsewhere]. TMM activation by the epidermal patterning factors (EPFs) and protease ligands (SDD) interferes with stomatal density and distribution [1,34], a possible feedback of stomatal development. Proteases are $\mathrm{pH}$ activated, therefore their output may depend on stomatal regulation. The so called mitogen activated protein kinases are in fact activated by oxidative stress, thus probably involved in stomata feedback as well.

At the same time, the brassinosteroid signaling is shown to inflict overproduction of YODA, the MAPKKK module, impairing the one cell minimal spacing rule [13] that can be implemented by ABA, a universal inhibitor of cell proliferation in development, participating in stomatal closure in response to draught [64], as well as affecting stomatal clustering through the wax biosynthesis pathways. Cell fates are thus met at the $\mathrm{ABA} /$ brassinosteroid/auxin interface.

\section{Conclusion}

Through history, stomatal evolution is correlated with growth habit and synecological events like the appearance of leaf canopies. In seed plant phylogeny, stomata displays evolutionary conservatism as well as radical restructuring related to the appearance of new growth forms, like the double-lip stomata in pachycaul cauliflorous bennettites. The general tendency of stomatal evolution is differentiation of stomatal and stomata-free zones, regular polarity, morphological elaboration, and aggregation of stomatal complexes. However, this tendency is reversed to irregular patterns and non-specialized subsidiary cells with reduction of vegetative growth, as in initial angiosperms. With better understanding of developmental regulation it will be possible to infer growth habit of ancestral forms from stomatal structure and vice versa.

Such correlations betray a complex regulation system commonly represented as a network of diverse regulation modules. The number of detected regulators rapidly 
increases; their effects broadly overlap, rendering the network useless for analytical purposes. Stomatal development is an exemplary network with thoroughly studied components; yet understanding of their complimentary roles requires a causal scheme linking endogenous developmental factors with environmental regulation.
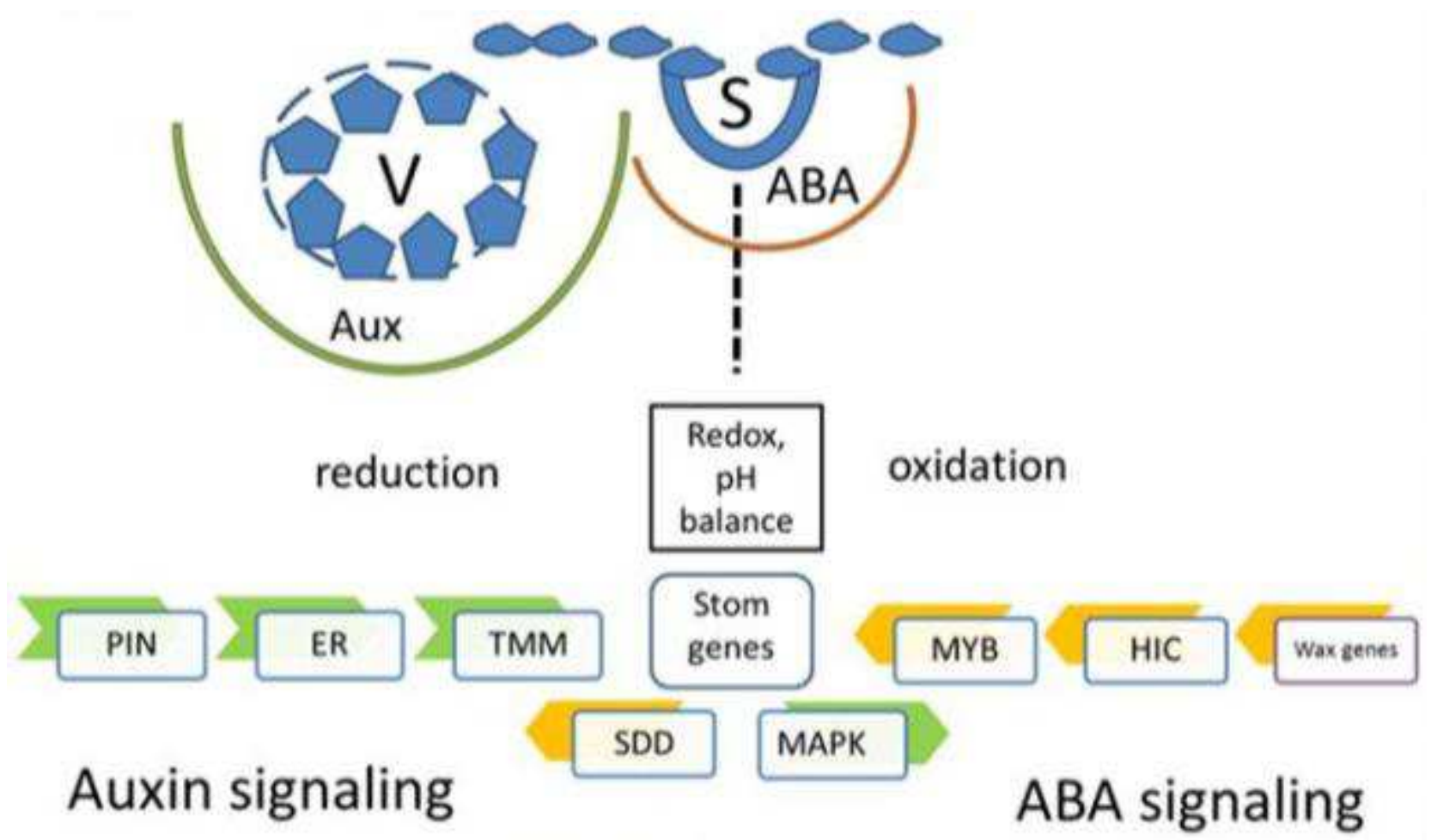

Figure 13. Scheme of stomatal regulation, representing a vascular bundle (V) and stoma (S) as the sources of antagonistic hormone, auxin and ABA, effects, roughly corresponding to reducing vs. oxidizing intercellular environments, with the redox reactions and $p H$ balanced by transpiration. At the bottom, phosphorylation cascades, starting with the plasma membrane PIN activation with auxin, meet ABA signaling through the wax biosynthesis synthases and regulators.

For stomata, environmental regulation is conferred by the sources of energy and matter involved in photosynthesis and moderated in respect to the immediate environments of the leaf surface air layer and gas concentrations in the subepidermal intercellular spaces. This way environmental regulation is related to leaf morphology, vascularization, secretory structures, and cutinization, the first line morpho-physiological system of adaptive responses to external pressure. These structures associate with auxin and ABA concentrations, attesting to the primacy of environmentally induced hormone regulation.

Environmental pressure, in particular light intensity, is sensed by the plasma membrane genes (PINs), directing the polar auxin transport. Auxin binding may trigger a series of complimentary receptor protein kinase cascades, involving ER with extracellular ligand binding domain, complementing TMM, with regulatory effects on expression of stomatal transcription factors downstream. The TMM liability to protease signaling may represent a feedback of stomatal development on account of a $\mathrm{pH}$ effect on activation of protease cascades. At the same time, the co-expressed wax biosynthesis genes associate with ABA signaling involved in draught response and regulation of stomatal closure (Fig. 13).
Thus stomata is the meeting place for auxins (brassinosteroids)/ABA signaling pathways and associated phosphorylation cascades, modulating expression of stomatal regulators that belong to the helix-loop-helix (bHLH) family of transcription factors broadly involved in cell differentiation processes in plants and animals.

Schematically, environmental pressure is countered with hormone regulated physiological work converted into chemical free energy potential of the receptor kinase cascades involved in upregulation of the target domain homeotic genes. The universality of this developmental scheme and biochemical compounds involved in its implementation are the basis of the whole plant developmental correlations.

\section{References}

[1] D. Berger and T.A. Altmann, "Subtilisin-like serine protease involved in the regulation of stomatal density and distribution in Arabidopsis thaliana," Genes and Dev., vol. 14, pp. 1119-1131, 2000

[2] J. A. Nadeau and F.D. Sack, "Control of stomatal distribution on the Arabidopsis leaf surface," Science, vol. 296, pp.1697-1700, 2002. 
[3] J. A. Nadeau and F. D. Sack, "Stomatal development in Arabidopsis," in The Arabidopsis Book, C. R. Somerville and E. M. Meyerowitz, Eds. Rockville MD: Am. Soc. Plant Biol., 2002, pp. 1543-8120.

[4] D. Bergmann, "Stomatal development: from neighbourly to global communication," Current Opinion in Plant Biol., vol. 9(5), pp. 478-483, 2006

[5] D. C. Bergmann, W. Lukowitz and C. R. Somerville, "Stomatal development and pattern controlled by a MAPKK kinase," Science, vol. 304, pp. 1494-1497, 2004.

[6] D. C. Bergmann and F. D. Sack, "Stomatal development," Annual Rev. Plant Biol., vol. 56, pp. 163 - 181, 2007.

[7] E. D. Shpak, C. T. Berthiaume, E. J. Hill and K. U. Torii, "Synergistic interaction of three ERECTA-family receptor-like kinases controls Arabidopsis organ growth and flower development by promoting cell proliferation," Development, vol. 131, pp. 1491-1501, 2004.

[8] K. Hara, R. Kajita, K. U. Torii, D. C. Bergmann and T. Kakimoto, "The secretory peptide gene EPF1 enforces the stomatal one-cell-spacing rule," Genes and Development, vol. 21(14), pp. 1720-1725, 2007.

[9] S. Casson and J. E. Gray, "Influence of environmental factors on stomatal development," New Phytologist, vol. 178(1), pp. 9-23, 2008

[10] M. M. Kanaoka, L. J. Pillitteri, H. Fujii, Y. Yoshida, N. L. Bogenschutz, J. Takabayashi, J.-K. Zhu and K.U. Toriial, "SCREAM/ICE1 and SCREAM2 specify three cell-state transitional steps leading to Arabidopsis stomatal differentiation," Plant Cell, vol. 20(7), pp. 1775-1785, 2008.

[11] L. J. Pillitteri, N. L. Bogenschutz, and K. U. Torii, "The bHLH protein, MUTE, controls differentiation of stomata and the hydathode pore in Arabidopsis," Plant and Cell Physiol., vol. 49(6), pp. 934-943, 2008.

[12] P. K. Jewaria, T. Hara, H. Tanaka, T. Kondo, S. Betsuyaku, S. Sawa, Y. Sakagami, S. Aimoto and T. Kakimoto, "Differential effects of peptides stomagen, EPF1, and EPF2 on activation of the MAP kinase MPK6 and the SPCH protein level," Plant Cell Physiol., vol. 49(6), pp. 934-943, 2008.

[13] M. Khan, W. Rozhon, J. Bigeard, D. Pflieger, S. Husar, A. Pitzschke, M. Teige, C. Jonak, H. Hirt and B. Poppenberger, "Brassinosteroid-regulated GSK3/shaggy-like kinases phosphorylate MAP kinase kinases, which control stomata development in Arabidopsis thaliana, J. Biol. Chem., vol. 288, pp. 7519-7527, March 2013.

[14] L. J. Pillitteri and J. Dong, "Stomatal Development in Arabidopsis," The Arabidopsis Book, vol. 11, pp. e0162, June 2013.

[15] K. M. Peterson, R. L. Rychel, K. U. Torii, "Out of the mouths of plants: the molecular basis of the evolution and diversity of stomatal development," Plant Cell, vol. 22(2), pp. 296-306, June 2010.

[16] V. A. Krassilov, "On classification of stomata," Palaeontol. J. (Moscow), vol. 1, pp. 102-109, 1968. (В. А. Красилов, “О классификации устьиц," Палеонтол. Ж., № 1, стр. 102-109, 1968).

[17] V. A. Krassilov, "Xeromorphism as climatic indicator,"
Palaeontol. J. (Moscow), vol. 2, pp. 3-12, 1997. (B.A Красилов, "Ксероморфизм как климатический индикатор, ” Палеонтол. Ж., № 26 стр. 3-12, 1997).

[18] V. A. Krassilov, "Electron microscopy of stomatal guard cells. Palaeontol. J. (Moscow), vol. 3, pp. 128-130, 1978a. (B. A. Красилов, “Электронная микроскопия замыкающих клеток устьиц,” Палеонтол. Ж., № 3, стр. 128-130, 1978а).

[19] V. A. Krassilov, "Bennettitalean stomata," Palaeobotanist, vol. 25 , pp. 179-184, 1978b.

[20] V. A. Krassilov, "Orestovia and the origin of vascular plants," Lethaia, vol. 14, pp. 235-250, 1981.

[21] V. A. Krassilov, "Scytophyllum and the origin of angiosperm leaf characters," Paleontol. J. (Moscow), vol. 29(A), pp. 63-75, 1995.

[22] V. A. Krassilov, Angiosperm origins: morphological and ecological aspects. Sophia: Pensoft, 1997, 270 pp.

[23] V. A. Krassilov, Cercidiphyllum and fossil allies: morphological interpretation and general problems of plant evolution and development. Sophia: Pensoft, 2010, 150 pp., 43 Plates.

[24] V. A. Krassilov and S. Polevova, "Devonian thalloid plants (Orestoviaceae) and associated spore tetrads," Palaeobotanist, vol. 61, pp. 359-372, 2012.

[25] V. A. Krassilov, Terrestrial palaeoecology and global change. Sophia: Pensoft, 2003, 464 pp.

[26] V. A. Krassilov and E. V. Karasev, "Paleofloristic evidence of climate change near and beyond the Permian - Triassic boundary," Palaeogeography, Palaeoclimatology, Palaeoecology, vol. 284(3-4), pp. 326-336, 2009.

[27] A. K. Srivastava, V.A. Krassilov and D. Agnihotri, "Peltasperms in the Permian of India and their bearing on Gondwanaland: reconstruction and climatic interpretation," Palaeogeography, Palaeoclimatology, Palaeoecology, vol. 310, pp. 393-399, 2011.

[28] V. A. Krassilov, Paleoecology of terrestrial plants. Basic Principles and techniques. N.Y.-Toronto: Wiley, 283 pp., 1975.

[29] S. Meyen, Fundamentals of paleobotany. New York: Chapman and Hall, 432 pp. 1987.

[30] T. N. Taylor, E. L. Taylor and M.Krings, Paleobotany: The biology and evolution of fossil plants. Amsterdam: Academic Press, 2009, 1252 pp.

[31] V. A. Krassilov, "Late Cretaceous gymnosperms from Sakhalin and the terminal Cretaceous event," Palaeontology, vol. 21, pp. 893-905, 1978c.

[32] G. Hagen, and T. Guilfoyle, "Auxin-responsive gene expression: genes, promoters and regulatory factors," Plant Mol. Biol., vol. 49(3-4), pp. 373-385, 2002.

[33] M. Yang and F. D. Sack, "The too many mouths and four lips Mutations Affect Stomatal Production in Arabidopsis," Plant Gell, vol. 7, pp. 2227-2239, 1995.

[34] K. Hara, T. Yokoo, R. Kajita, T. Onishi, S. Yahata, K. M. Peterson, K. U. Torii and T. Kakimoto, "Epidermal cell density is autoregulated via a secretory peptide, EPIDERMAL PATTERNING FACTOR 2 in Arabidopsis 
leaves," Plant Cell Physiol., vol. 50(6), pp. 1019-1031, 2009.

[35] C. A. MacAlister, K. Ohashi-Ito and D. C. Bergmann, "Arabidopsis FAMA controls the final proliferation/differentiation switch during stomatal development," Nature, vol. 445, pp. 537-540, February 2007.

[36] J. E. Gray, G. H. Holroyd, F. M. van der Lee, A. R. Bahrami, P. C. Sijmons, F. I. Woodward, W. Schuch and A. M. Hetherington, "The $\mathrm{HIC}$ signaling pathway links $\mathrm{CO}_{2}$ perception to stomatal development," Nature, vol. 408, pp. 713-716, December 2000.

[37] U. Schlüter, M. Muschak, D. Berger and T. Altmann, "Photosynthetic performance an Arabidopsis mutant with elevated stomatal density (sdd1-1) under different light regimes," J. Exp. Bot., vol. 54(383), pp. 867-874, February 2003.

[38] B. Luo, X.-Y. Xue, W.-L. Hu, L.-J. Wang and X.-Y. Chen, "An ABC transporter gene of Arabidopsis thaliana, AtWBC11, is involved in cuticle development and prevention of organ fusion," Plant Cell Physiol., vol. 48(12), pp. 1790-1802, December 2007.

[39] D. Panikashvili, S. Savaldi-Goldstein, T. Mandel, T. Yifhar, R. B. Franke, R. Hofer, L. Schreiber, J. Chory and A. Aharoni, The Arabidopsis DESPERADO/AtWBC11 transporter is required for cutin and wax secretion," Plant Physiol., vol. 145(4), pp. 1345-1360, December 2007.

[40] P. J. Seo, S. B. Lee, M. Ch. Suh, M.-J. Park, Y. S. Go and Ch.-M. Parka, "The MYB96 transcription factor regulates cuticular wax biosynthesis under drought conditions in Arabidopsis," Plant Cell, vol. 23, pp. 1138-1152, March 2011.

[41] H. Candela, A. Martinez-Laborda and J. L. Micol, "Venation pattern formation in Arabidopsis thaliana vegetative leaves," Develop. Biol., vol. 205(1), pp. 205-216, 1999.

[42] Y. Kovtun, W. L. Chiu, G. Tena and J. Sheen, "Functional analysis of oxidative stress-activated mitogenactivated protein kinase cascade in plants," Proc. Natl. Acad. Sci. U S A, vol. 97(6), pp. 2940-2945, March 2000.

[43] R. Aloni, "Foliar and axial aspects of vascular differentiation: hypotheses and evidence," J. Plant Growth Regul., vol. 20, pp. 22-34, February 2001.

[44] R. Aloni, M. Langhans, E. Aloni, E. Dreieicher, C. I. Ullrich, "Root-synthesized cytokinin in Arabidopsis is distributed in the shoot by the transpiration stream," J. Exp. Bot., vol. 56(416), pp. 1535-1544, June 2005.

[45] N. K. Clay and T. Nelson, "Arabidopsis thickvein mutation affects vein thickness and organ vascularization, and resides in a provascular cell-specific spermine synthase involved in vein definition and in polar auxin transport," Plant Physiol., vol. 138(2), pp. 767-777, June 2005.

[46] E. Scarpella, D. Marcos, J. Friml and T. Berleth, "Control of leaf vascular patterning by polar auxin transport," Genes Dev., vol. 20(8), pp. 1015-1027, April 2006.

[47] F.I. Woodward, "Stomatal numbers are sensitive to $\mathrm{CO} 2$ increases from preindustrial levels," Nature, vol. 327, pp. 617-618, June 1987.

[48] F. I. Woodward and C. K. Kelly, "The influences of $\mathrm{CO} 2$ concentration on stomatal density," New Phytologist, vol. 131(3), pp. 311-327, November 1995.

[49] J. A. Lake, W.P. Quick, D. J. Beerling and F.I. Woodward, "Signals from mature to new leaves," Nature, vol. 411, pp. 154, May 2001.

[50] T. Lawson, J. Craigon, C. R. Black, J. J., Colls, G. Landon and J.D. Weyers, "Impact of elevated $\mathrm{CO}_{2}$ and $\mathrm{O} 3$ on gas exchange parameters and epidermal characteristics in potato (Solanum tuberosum L.)," J. Exp. Bot., vol. 53(369), pp. 737-746, 2002

[51] S. Driscoll, A. Prins, E. Olmos, K. Kunert, C. Foyer, "Specification of adaxial and abaxial stomata, epidermal structure and photosynthesis to $\mathrm{CO}_{2}$ enrichment in maize leaves,” J. Exp. Bot., vol. 57, pp. 381-390, 2006.

[52] G. J. Retallak, "A 300-million-year record of atmospheric carbon dioxide from fossil plant cuticles," Nature, vol. 411, pp. 287-290, May 2001.

[53] G. Ågren, "Limits to plant production,” J. Theor. Biol., vol. 113, pp. 89-92, March 1985.

[54] O. Kossover, Z. Frenkel, A. Korol and E. Nevo, "Genetic diversity and stress of Ricotia lunaria in "Evolution Canyon," Israel," J. Hered. vol. 100(4), pp. 432-440, March 2009.

[55] H. Kazama, H. Dan, H. Imaseki and G. O. Wasteneys, "Transient exposure to ethylene stimulates cell division and alters the fate and polarity of hypocotyl epidermal cells," Plant Physiol., vol. 134(4), pp. 1614-1623, April 2004.

[56] S. Schoch, C. Hehlein and W. Rudiger, "Influence of anaerobiosis on chlorphyll biosynthesis in greening oat seddlings (Avena sativa L.)," Plant Physiol., vol. 66, pp. 576-569, October 1980.

[57] W. D. Teale, I. A. Paponov and K. Palme, "Auxin in action: Signalling, transport and the control of plant growth and development," Nat. Rev. Mol. Cell Biol., vol. 7(11), pp. 847-859, November 2006.

[58] X. Chen, S. M. Goodwin, V. L. Boroff, X. Liu and M. A. Jenks, "Cloning and characterization of the WAX2 gene of Arabidopsis involved in cuticle membrane and wax production," Plant Cell, vol. 15(5), pp. 1170-1185, May 2003.

[59] K .D. Cameron, M. A. Teece and L.B. Smart, "Increased accumulation of cuticular wax and expression of lipid transfer protein in response to periodic drying events in leaves of tree tobacco," Plant Physiol., vol. 140(1), pp. 176-183, January 2006.

[60] Y. Xiang, Y. Huang and L. Xiong, "Characterization of stress-responsive CIPK genes in rice for stress tolerance improvement," Plant Physiol., vol. 144(3), pp. 1416-1428, July 2007.

[61] E. Benková, M. Michniewicz, M. Sauer, T. Teichmann, D. Seifertová, G. Jürgens and J. Friml, "Local, efflux-dependent auxin gradients as a common module for plant organ formation," Cell, vol. 115(5), pp. 591-602, November 2003.

[62] A. Paponov, W. D. Teale, M. Trebar, I. Blilou and K. Palme, "The PIN auxin efflux facilitators: evolutionary and functional perspectives," Trends Plant Sci., vol. 10, pp. 170-177, April 2005. 
[63] K. U. Torii, N. Mitsukawa, T. Oosumi, Y. Matsuura, R. Yokoyama, R. F. Whittier and Y. Komeda, "The Arabidopsis ERECTA gene encodes a putative receptor protein kinase with extracellular leucine-rich repeats," Plant Cell, vol. 8(4), pp. 735-746, April 1996.

[64] J. I. Schroeder, J. M. Kwak and G. J. Allen, "Guard cell abscisic acid signalling and engineering drought hardiness in plants," Nature, vol. 410, pp. 327-330, March 2001. 